\title{
EL MAR COMO ORGANIZACIÓN SOCIAL EN EL NORTE DE MÉXICO: CASO DE LA ACUACULTURA EN GUASAVE SINALOA
}

\author{
Leyva Castellanos, A. $^{1}$ \& Báez Puerta, t. ${ }^{1}$
}

\begin{abstract}
RESUMEN
El mar, a través del sistema de cooperativas y del sistema de granjas acuícolas, manifiesta un nuevo reparto espacial marítimo, el de los usos sociales del mar que implican procesos de mayor demanda desde la perspectiva organizacional, y alienta la generación de políticas públicas de nueva generación.

Estudiar la organización social de las zonas productivas del mar de Cortés en el municipio de Guasave, permite identificar los impactos sociales articulados al cambio climático de la zona, con el objetivo de producir políticas públicas municipales.

Cada vez es más visible las crisis de escalas en nuestras sociedades; la cultura acuícola insta procesos novedosos y demanda dinámicas transdisciplinares para la integración del conocimiento. Son 90 granjas de operación de un total de 102 unidades que son pioneras en biotecnología y han colapsado en un proceso deficitario con una pérdida de producción hasta el $70 \%$.

Palabras clave: integración del conocimiento, transdisciplina, organización social.
\end{abstract}

\section{SUMMARY}

\section{The sea as a social organization in northern Mexico: Guasave case aquaculture in Sinaloa.}

The sea across the system of cooperatives and of the system of aquicultural farms demostrates a new spatial maritime distribution, the social uses of the sea imply processes of major demand from the perspective organizacional and there breathes the generation of public policies of new generation.

To study the social organization of the productive zones of the Sea of Cortés in Guasave's municipality allows to identify the social impacts articulated to the climate change of the zone; with the aim to produce public municipal policies.

Every time it is more visible the crises of scales in our companies; the aquicultural culture urges new processes and demands dynamics transdisciplinares for the integration of the knowledge.

Key words: integration of knowledge, transdisciplinary, organization social.

1.-Escuela de Ciencias Económicas y Administrativas. Universidad Autónoma de Sinaloa Guasave. Sinaloa, México.

Manuscrito recibido el 19 de diciembre de 2013 y aceptado para su publicación el 4 de abril de 2014. 